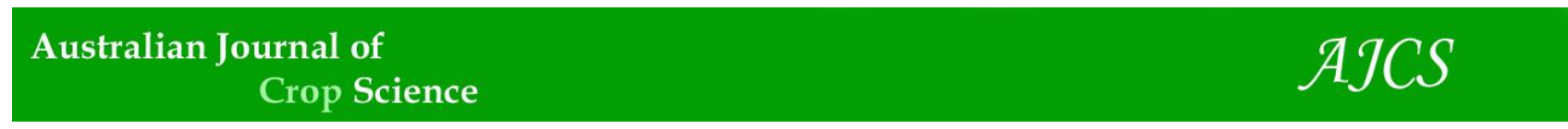

AJCS 11(12):1665-1674 (2017)

ISSN:1835-2707

doi: 10.21475/ajcs.17.11.12.pne921

\title{
Changes in growth, oxidative metabolism and essential oil composition of lemon balm (Melissa officinalis L.) subjected to salt stress
}

\author{
Cristine Bonacina ${ }^{1}$, Cláudia Borsari Trevizan¹, Juliana Stracieri², Tiago Benedito dos Santos ${ }^{3}$ José \\ Eduardo Gonçalves $^{4,5}$, Zilda Cristiani Gazim ${ }^{1}$, Silvia Graciele Hülse de Souza ${ }^{*}$
}

\author{
${ }^{1}$ Programa de Pós-graduação em Biotecnologia Aplicada à Agricultura, Universidade Paranaense - UNIPAR, \\ Praça Mascarenhas de Moraes, 4282, Umuarama, PR, Brazil \\ ${ }^{2}$ Universidade Estadual de Maringá - UEM, Estrada da Paca s/n, 87502-970, Umuarama, PR, Brazil \\ ${ }^{3}$ Universidade do Oeste Paulista - Unoeste, Rodovia Raposo Tavares s/n, 19067-175, Presidente Prudente, SP, \\ Brazil \\ ${ }^{4}$ Mestrado em Tecnologia Limpas, UniCesumar, Av. Guedner, 1610, Maringá, PR, Brazil \\ ${ }^{5}$ Instituto Cesumar de Ciência, Tecnologia e Inovação - ICETI, Maringá, PR, Brazil
}

*Corresponding author: silviahulse@prof.unipar.br

\begin{abstract}
Agricultural crops are severely affected by salinity. Recent studies have shown that salt stress signaling components affect plant metabolism and stimulate the accumulation of organic osmolytes and antioxidant substances. This work aimed at assessing the growth and development of lemon balm, Melissa officinalis L., subjected to salt stress, as well as its antioxidant response, essential oil composition, and essential oil yield $(\%)$. A completely randomized experimental design was conducted under greenhouse conditions, where 30-days-old lemon balm plants were treated with different $\mathrm{NaCl}$ concentrations $(0,50,100,150$ and $200 \mathrm{mM})$ for sixty days. The highest concentrations $(150 \mathrm{mM}$ and $200 \mathrm{mM} \mathrm{NaCl})$ caused significant reductions in shoot height, shoot fresh mass, relative water content, water activity and chlorophyll production due to changes in osmotic activity. The activities of superoxide dismutase (SOD) and catalase (CAT) increased in plants subjected to salinity. In addition, membrane damage (DM) increased with increase in $\mathrm{NaCl}$ concentration. The yield of the essential oils decreased but the number of compounds increased in all the $\mathrm{NaCl}$ treatments. The compounds neryl-acetate and geranyl-acetate were detected at 100,150 and $200 \mathrm{mM} \mathrm{NaCl}$, suggesting that under salt stress, lemon balm plants activate the metabolic pathways for the production of terpenoids, consequently producing monoterpenes. Salinity negatively affected most of the parameters evaluated in lemon balm plants. Our results show that lemon balm plants are tolerant to low concentrations of salinity (up to $50 \mathrm{mM}$ ) as proved by their distinct metabolic responses.
\end{abstract}

Keywords: abiotic stress, essential oils, secondary metabolites, $\alpha$-citral, neral, citronellal.

Abbreviations: ROS_reactive oxygen species, GPX_glutathione peroxidase, GR_glutathione reductase, CAT_catalase, APX_ascorbate peroxidase, PPO_polyphenol oxidase, EO_essential oil, SH_shoot heights, SFM_shoot fresh masses, RWC_relative water content, FM_fresh mass weight, DM_dry mass weight, TM_turgid mass weight, aw_water activity, REL_relative electrolyte leakage, L1_initial electric conductivity of the extract, L2_final electric conductivity of the extract, DM_damage in the membrane, NBT_nitro-blue tetrazolium, GC/MS_gaschromatograph/mass spectrometer, RI_retention indices, ANOVA_analysis of variance, CA_cluster analysis, PCA_principal component analysis, UPGMA_Unweighted Pair Group Method with Arithmetic Mean.

Introduction

Lemon balm (Melissa officinalis L.) is a medicinal plant belonging to the family Lamiaceae. It was originally found in Mediterranean countries and is commonly cultivated worldwide due to its economic importance (Younesi and Moradi, 2015; Szabó et al., 2016). Also known as the balm, common balm, or balm mint, its leaves are used as tranquilizer and sedative (Morgan, 1994). The essential oil from the balm tree is used for the manufacture of various products, such as condiments, flavoring agents, natural insecticides and insect repellents, thus serving the pharmaceutical, food, beverage, cosmetic and chemical industries (Bagdat and Cosge, 2006; Abbaszadeh et al., 2009; Verma et al., 2015). The leaves of balm contain high quantities of secondary metabolites. These include citronellal, citronellol, linalool, neral, geranial and geraniol (both isomers of citral), rosmarinic acid, phenolic acid, flavoglycoside acid, caffeic acid, isoquercitin, apigenin (apigenin-7-O-glucoside), beta-carophyllene, tannins, flavonoids, luteolin, hesperidin and others (Moradkhani et al., 2010; Argyropoulos and Müller, 2014). The quality and continuous production of essential oils is very important to supply market demands and the industry requirements, even under adverse environmental conditions such as drought, salinity, and extreme temperatures (Silva, 2002; Çoban and Baydar, 2016). These adverse conditions strongly affect the biosynthesis and production of secondary metabolites in medicinal and aromatic plants, causing increase or decrease in the essential oils' yield and changes in their composition (Lopes and Gobbo-Neto, 2007; Kim et al., 2010; Tonelli et al., 2014). Abiotic stresses such as drought and salinity cause negative effects on growth and development of medicinal plants (Khorasaninejad et al., 2010). In response to these 
stresses, plants activate regulatory complexes to neutralize the harmful effects and restore cell homeostasis (Suzuki et al., 2012). Salinity reduces plant growth by decreasing the plant's water potential, breaking various cell metabolisms, altering enzymatic activities thereby causing nutritional imbalances, increasing accumulation of solutes, or combining all these events (Munns and Tester, 2008; Tounekti et al, 2012).

Plants can produce and accumulate reactive forms of oxygen (ROS) as a defense mechanism against injuries caused by stress (Jaspers and Kangasjarvi, 2010). The commonly observed ROS are the oxygen molecules with superoxide anion radical $\left(\mathrm{O}_{2}{ }^{*}\right)$, hydroxyl radical $\left(\mathrm{OH}^{*}\right)$, singlet oxygen $\left(\mathrm{O}_{2}\right)$ and hydrogen peroxide $\left(\mathrm{H}_{2} \mathrm{O}_{2}\right)$. The antioxidant enzymes such as glutathione peroxidase (GPX), glutathione reductase (GR), catalase (CAT), ascorbate peroxidase (APX), and polyphenol oxidase (PPO) are activated to protect cells from oxidative damage ( $\mathrm{Hu}$ et al., 2009; Gill and Tuteja, 2010; Tripathy and Oelmüller, 2012). Studies on different types of stress and on growth and development, metabolism, and composition of the essential oils of medicinal plants have gained high momentum. It has been reported that each type of stress differently influences plant metabolism and essential oil composition (Alvarenga et al., 2011; Meira et al., 2012; Kasrati et al., 2014). However, few studies have demonstrated the effect of salt stress on development, metabolism, and composition of essential oils of M. officinalis, in addition to physiological and biochemical responses (Ozturk et al., 2004; Khalid and Cail, 2011). Therefore, this study aimed at evaluating the effects of salt stress levels in M. officinalis plants on morphological aspects, antioxidant responses, and essential oil yield and composition.

\section{Results and discussion}

\section{Effects of salt stress on development of lemon balm plants}

The development of lemon balm plants decreased with the addition of different concentrations of $\mathrm{NaCl}$. The salt stress levels caused by 50,100, 150 and $200 \mathrm{mM} \mathrm{NaCl}$ affected plant height and shoot fresh mass accumulation (Figs. 1A and 1B.). A decreased $17.97 \% \mathrm{SH}$ and $48.36 \% \mathrm{SFM}$ was observed at $200 \mathrm{mM} \mathrm{NaCl}$, in comparison with control (Table 1). RWC and WA decreased with the increase in $\mathrm{NaCl}$ concentrations (Figs. 1C and 1D.). Further reduction in RWC (\%) (Fig. 1C.) and WA (Fig. 1D.) were observed at concentrations of 150 and $200 \mathrm{mM} \mathrm{NaCl}$.

Plant development and water accumulation are related factors. The reduced development of lemon balm plants subjected to salinity is probably as a result of the $\mathrm{NaCl}$ action on plants that causes the disturbance in their water relations, especially with respect to turgor, due to changes in osmolarity (Yasar, 2006; Hussain et al.,2011). It means that there is a reduction in water absorption, and consequently, a decrease in water content in the plant tissue and in the turgor, as observed in our work (Fig. 1.). Therefore, cell elongation in plants is inhibited by the reduced pressure of turgescence, under stress conditions. On the same way, the salt stress probably decreases the accumulation of photo assimilates due to the closure of stomatal cells, restricting carbon dioxide absorption and consequently, reducing the availability of metabolites to perform cell division (Baghalian et al., 2011). As consequence, some mechanisms as mitosis, elongation, and expansion of cells are hampered, resulting in reduced plant height and impaired growth (Farooq et al., 2009; Negrão et al., 2017).
Studies on different $\mathrm{NaCl}$ concentrations applied to medicinal plants demonstrate similar results. Tounekti et al. (2012) verified great reductions in the growth of Salvia officinalis at $100 \mathrm{mM} \mathrm{NaCl}$. Khorasaninejad et al. (2010) observed the same response in the shoot fresh mass of Mentha piperita $\mathrm{L}$. at $100 \mathrm{mM} \mathrm{NaCl}$. Kasrati et al. (2014) also observed a low production of shoot fresh mass in a menthe species subjected to $100 \mathrm{mM} \mathrm{NaCl}$ and $150 \mathrm{mM} \mathrm{NaCl}$.

Fig. 2 demonstrates that salinity caused physiological disturbances in lemon balm plants. The severity of leaf lesions increased with the increase in $\mathrm{NaCl}$ concentrations. The first visual symptoms of salt stress were chlorosis and subsequently leaf drying. Some lemon balm plants lost their vitality from $150 \mathrm{mM} \mathrm{NaCl}$. Such changes occurred due to the release of $\mathrm{Na}^{+}$and $\mathrm{Cl}^{-}$in the plant cell tissues caused by the increased concentrations of $\mathrm{NaCl}$, resulting in structural damages that led to dehydration and cell death (Munns, 2002).

Total chlorophyll content diminished at $200 \mathrm{mM} \mathrm{NaCl}$ in comparison with control (Fig. 3A.). As a consequence, yellowing was observed in the leaves (Fig. 2.). It occurred because salt stress normally hampers the entry of water into cell metabolisms. Since water participates in the production of chlorophyll, the decrease in the plant's photosynthesis may result in the plant death (Kumar et al., 2014).

With an increase in $\mathrm{NaCl}$, the number of electrolytes released was increased. The highest DM\% was observed in plants subjected to $200 \mathrm{mM} \mathrm{NaCl}$ (Fig. 3B.). Kere et al. (2016) observed that $\mathrm{NaCl}$ caused damage to plasma membranes of different genotypes of Cucumis sativus L., either resistant (11411S and 11432S) or sensitive (HH1-8-57 and 11439S) to salinity. However, the authors reported higher electrolyte leakage in the sensitive genotypes.

\section{Response of antioxidant enzymes to salt stress}

Many studies have demonstrated alterations in the activity of antioxidant enzymes as a response to abiotic stresses, suggesting that the increase in such activities is closely linked to stress tolerance (Chen et al., 2014; Choundhury et al., 2016). Understanding plant responses to salt stress will lead to decipher a cascade of biochemical events and complex gene expressions (Bray et al., 2000). In this study, the activity of antioxidant enzymes was differentially modulated by $\mathrm{NaCl}$ in the M. officinalis leaves. An increased SOD activity was observed at $200 \mathrm{mM} \mathrm{NaCl}$ in comparison with control (Fig. 4A.). The maximum activity of the CAT enzyme was verified at $150 \mathrm{mM} \mathrm{NaCl}$. The increased activity of SOD and CAT is related to the maintenance of levels of lipid peroxidation under salt stress conditions (Alscher et al., 2002).

In this study, the CAT activity increased up to the concentration of $150 \mathrm{mM} \mathrm{NaCl}$; therefore, this enzyme was effective to protect cells against oxidation. Among the $\mathrm{H}_{2} \mathrm{O}_{2}$ degrading enzymes, catalase does not consume equivalent cell reducers, removing $\mathrm{H}_{2} \mathrm{O}_{2}$ produced in cells under stress conditions through efficient mechanisms (Scandalios, 2005). The CAT enzyme is found in peroxisome and cytosol and is indispensable for cellular detoxification, catalyzing the transformation of $\mathrm{H}_{2} \mathrm{O}_{2}$ into molecular oxygen and water (Gill and Tuteja, 2010). Lledias et al. (1998) suggested that the CAT enzyme is so efficient that it cannot be saturated with $\mathrm{H}_{2} \mathrm{O}_{2}$ at any concentration of peroxide. A combined action of CAT and SOD converts the toxic $\mathrm{O}_{2}^{-}$and $\mathrm{H}_{2} \mathrm{O}_{2}$ into the water and molecular oxygen, avoiding cell damages under adverse environmental conditions (Reddy et al., 2004).The increase in the activity of these enzymes is related to the tolerance of plants to oxidative stress. 
Table 1. Inhibition (\%) of the shoot height (SH) and the shoot fresh mass (SFM) of plants subjected to different concentrations of $\mathrm{NaCl}$.

\begin{tabular}{lll}
\hline \multirow{2}{*}{ Treatments with $\mathrm{NaCl}(\mathrm{mM})$} & \multicolumn{2}{c}{ \% Inhibition } \\
\cline { 2 - 3 } & $\mathrm{SH}$ & $\mathrm{SFM}$ \\
\hline 50 & $6.98 \mathrm{~b}^{*}$ & $0.58 \mathrm{c}$ \\
100 & $8.46 \mathrm{~b}$ & $27.34 \mathrm{~b}$ \\
150 & $10.50 \mathrm{~b}$ & $46.48 \mathrm{a}$ \\
200 & $17.97 \mathrm{a}$ & $48.36 \mathrm{a}$ \\
\hline *Means followed by the same letter did not differ significantly at $\mathrm{p}<0.05$, according to Tukey's test.
\end{tabular}
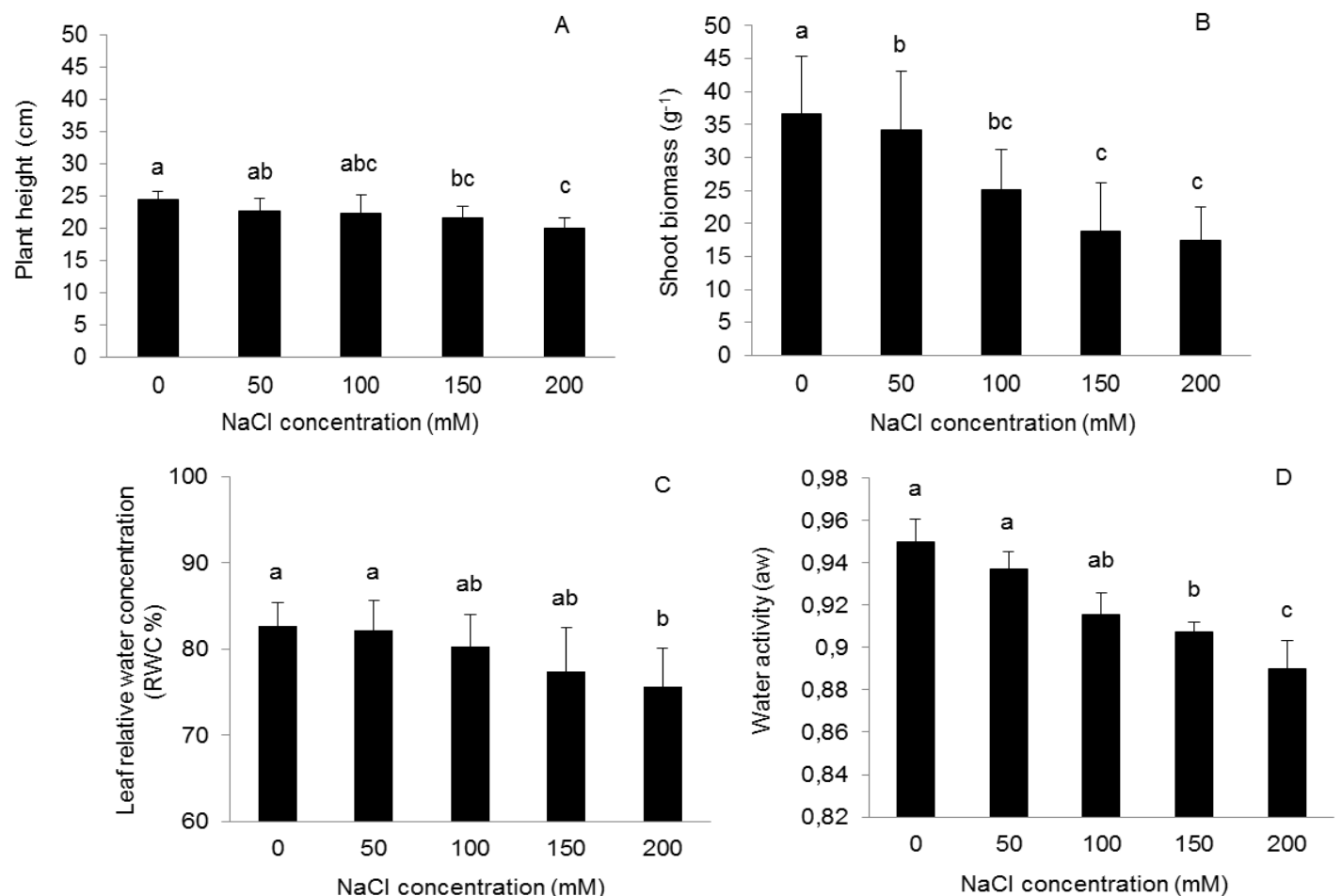

Fig 1. Effects of salt stress on plant height (A), shoot biomass (B), relative water content in leaves (C), and water activity (D). Means with the same letter did not differ significantly at $\mathrm{p}<0.05$, according to Tukey's test.

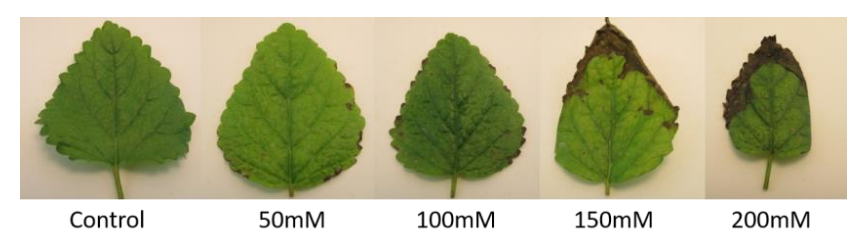

Fig 2. Leaf toxicity symptoms on lemon balm leaves (Melissa officinalis L.) subjected to different $\mathrm{NaCl}$ concentrations for sixty days.
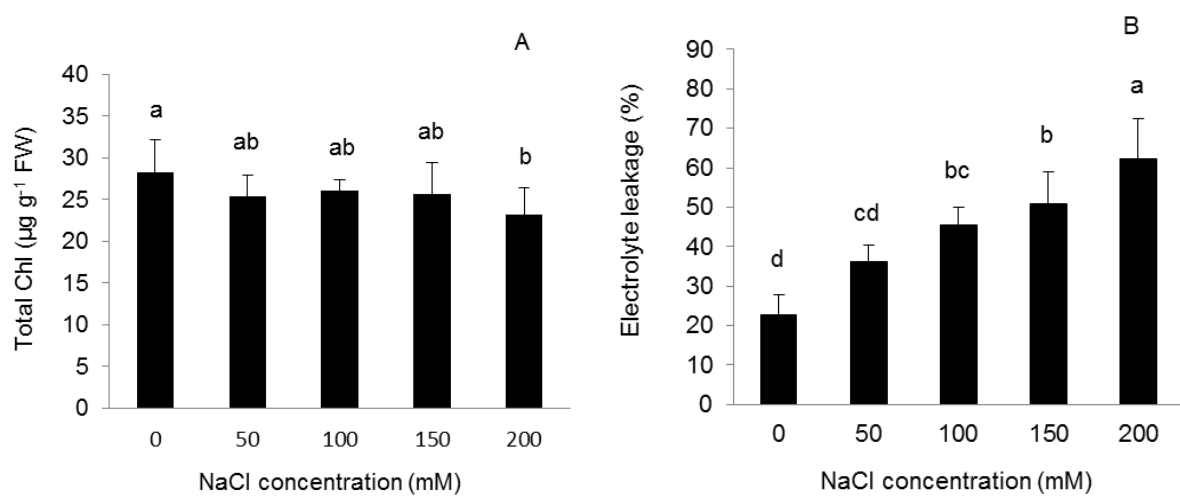

Fig 3. Effects of saline stress on total Chl (A) and electrolyte leakage (B) in Melissa officinalis L plants. Means followed by the same letter did not differ significantly at $\mathrm{p}<0.05$, according to Tukey's test. 
Table 2. Chromatography (GC/MS) of the essential oils of lemon balm plants ( $M$. officinalis $\mathrm{L}$ ) subjected to different concentrations of $\mathrm{NaCl}(\mathrm{T} 50=50 \mathrm{mM} ; \mathrm{T} 100=100 \mathrm{mM}$; $\mathrm{T} 150=150 \mathrm{mM}$ and $\mathrm{T} 200=200 \mathrm{mM})$ and control $(\mathrm{TC}=0 \mathrm{mM}$ ).

\begin{tabular}{|c|c|c|c|c|c|c|c|c|c|c|c|c|c|c|c|c|c|}
\hline \multirow[b]{3}{*}{ Peak $^{\mathrm{a}}$} & \multirow{3}{*}{ Coumpounds } & \multirow[b]{3}{*}{$\mathrm{RI}^{\mathrm{b}}$} & \multicolumn{5}{|c|}{ Area $(\%)$} & \multirow[b]{3}{*}{$\mathrm{IM}^{\mathrm{c}}$} & \multirow[b]{3}{*}{ Peak $^{\mathrm{a}}$} & \multirow[b]{3}{*}{ Coumpounds } & \multirow[b]{3}{*}{$\mathrm{RI}^{\mathrm{b}}$} & \multicolumn{5}{|c|}{ Area (\%) } & \multirow[b]{3}{*}{$\mathrm{IM}^{\mathrm{c}}$} \\
\hline & & & & & \multicolumn{3}{|c|}{ Treatment } & & & & & \multicolumn{5}{|c|}{ Treatment } & \\
\hline & & & $\mathrm{TC}$ & T50 & $\mathrm{T} 100$ & T150 & T200 & & & & & $\mathrm{TC}$ & T50 & T100 & T150 & T200 & \\
\hline & \multicolumn{7}{|c|}{ Monoterpenes Hydrocarbons } & & 29 & Geraniol & 1247 & - & 2.93 & 2.37 & 3.04 & 3.65 & $\mathrm{a}, \mathrm{b}, \mathrm{c}$ \\
\hline 1 & $\alpha$-pinene & 936 & $\mathrm{~T}$ & 0.33 & 0.26 & $\mathrm{t}$ & 0.33 & $a, b, c$ & 30 & $\mathrm{n}, \mathrm{i}$ & - & - & - & - & - & 0.65 & $\mathrm{a}, \mathrm{c}$ \\
\hline 2 & Sabinene & 976 & $\mathrm{~T}$ & 0.09 & $\mathrm{t}$ & $\mathrm{t}$ & 0.11 & $a, b, c$ & 31 & $\alpha$-citral & 1276 & 45.05 & 42.22 & 41.38 & 41.73 & 40.45 & $a, b, c$ \\
\hline 3 & $\beta$-pinene & 979 & $\mathrm{~T}$ & 0.32 & 0.23 & $\mathrm{t}$ & 0.31 & $\mathrm{a}, \mathrm{c}$ & 32 & Neryl acetate & 1385 & - & - & - & 4,56 & - & $a, b, c$ \\
\hline 4 & Myrcene & 991 & 5.05 & 5.34 & 5.59 & 4.79 & 6.03 & $\mathrm{a}, \mathrm{b}, \mathrm{c}$ & 33 & Geranyl acetate & 1390 & - & - & 2,06 & - & 3,72 & $a, b, c$ \\
\hline 5 & $\begin{array}{l}\alpha- \\
\text { phellandrene }\end{array}$ & 1005 & $\mathrm{~T}$ & 0.35 & 0.29 & $\mathrm{t}$ & 0.38 & $\mathrm{a}, \mathrm{b}, \mathrm{c}$ & & \multicolumn{7}{|c|}{ Sesquiterpenes Hydrocarbons } & \\
\hline 6 & $\delta$-3-carene & 1011 & $\mathrm{~T}$ & $\mathrm{t}$ & $\mathrm{t}$ & - & $\mathrm{t}$ & $a, b, c$ & 34 & Trans-caryophyllene & 1413 & 2.69 & 2.93 & 3.17 & 3.25 & 2.85 & $a, b, c$ \\
\hline 7 & p-cymene & 1027 & $\mathrm{~T}$ & - & $\mathrm{t}$ & $\mathrm{t}$ & 0.19 & $a, b, c$ & 35 & Trans- $\alpha$-bergamotene & 1443 & - & - & $\mathrm{t}$ & - & - & $a, b, c$ \\
\hline 8 & o-cymene & 1027 & - & 0.18 & 0.4 & - & - & $\mathrm{a}, \mathrm{b}, \mathrm{c}$ & 36 & Aromadendrene & 1452 & - & - & 0.47 & - & - & $a, b, c$ \\
\hline 9 & Limonene & 1031 & $\mathrm{~T}$ & - & $\mathrm{t}$ & - & - & $\mathrm{a}, \mathrm{b}, \mathrm{c}$ & 37 & $\alpha$-humulene & 1479 & - & $\mathrm{t}$ & $\mathrm{t}$ & $\mathrm{t}$ & $\mathrm{t}$ & $a, b, c$ \\
\hline 10 & $\begin{array}{l}\beta- \\
\text { phellandrene }\end{array}$ & 1031 & $\mathrm{~T}$ & 0.38 & - & $\mathrm{t}$ & 0.45 & $a, b, c$ & 38 & $\alpha$-curcumene & 1484 & - & - & $\mathrm{t}$ & - & - & $\mathrm{a}, \mathrm{b}, \mathrm{c}$ \\
\hline 11 & $\mathrm{n}, \mathrm{i}$ & - & - & 0.36 & 0.43 & - & 0.48 & $\mathrm{a}, \mathrm{c}$ & 39 & $\alpha$-amorphene & 1494 & - & 0.69 & - & - & - & $a, b, c$ \\
\hline 12 & $\gamma$-terpinene & 1033 & 0.45 & - & - & 0.41 & - & $a, b, c$ & 40 & Germacrene-D & 1524 & - & - & $\mathrm{t}$ & - & - & $a, b, c$ \\
\hline \multirow[t]{2}{*}{13} & \multirow{2}{*}{\multicolumn{7}{|c|}{ Oxygenated Monoterpenes }} & $a, b, c$ & 41 & $\alpha$-zingiberene & 1581 & - & - & $\mathrm{t}$ & - & - & $a, b, c$ \\
\hline & & & & & & & & & 42 & $\delta$-cadinene & 1672 & - & - & 1.34 & - & - & $a, b, c$ \\
\hline 14 & Linalool & 1104 & 1.04 & 0.35 & 0.47 & 0.65 & 1.16 & $a, b, c$ & & Oxygenated sesquiter & nes & & & & & & \\
\hline 15 & $\mathrm{n}, \mathrm{i}$ & 1105 & - & - & - & - & - & $a, b, c$ & 43 & Tumerol & 1705 & - & - & $\mathrm{t}$ & - & - & $a, b, c$ \\
\hline 16 & Trans-thujone & 1147 & 1.09 & - & - & - & 0.55 & $\mathrm{a}, \mathrm{b}, \mathrm{c}$ & 44 & Caryophyllene-oxide & 2108 & - & - & $\mathrm{t}$ & - & - & $\mathrm{a}, \mathrm{b}, \mathrm{c}$ \\
\hline 19 & Isopulegol & 1155 & $\mathrm{~T}$ & 1.36 & 1.2 & 1.09 & - & $a, b, c$ & & & & & & & & & \\
\hline 20 & Citronellal & 1167 & 9.89 & 8.93 & 5.87 & 5.51 & 9.13 & $a, b, c$ & \multicolumn{3}{|c|}{ Groups of compounds (\%) } & & & & & & \\
\hline 21 & Lavandulol & 1169 & - & 0.79 & - & - & - & $a, b, c$ & \multicolumn{3}{|c|}{ Monoterpenes Hydrocarbons } & 5.50 & 7.35 & 8.60 & 7.14 & 8.28 & \\
\hline 22 & $\begin{array}{l}\text { Methyl- } \\
\text { chavicol }\end{array}$ & 1180 & - & - & 0.61 & - & - & $a, b, c$ & \multicolumn{3}{|c|}{ OxigenatedMonoterpenes } & 90.90 & 86.14 & 81.40 & 89.61 & 87.84 & \\
\hline 23 & Estragol & 1184 & - & - & _- & _- & 0.62 & $a, b, c$ & \multirow{3}{*}{\multicolumn{3}{|c|}{$\begin{array}{l}\text { Sesquiterpenes Hydrocarbons } \\
\text { Oxygenated Sesquiterpenes } \\
\text { EO yield }(\%)\end{array}$}} & 2.69 & 3.62 & 4.98 & 3.25 & 2.85 & \\
\hline 24 & Citronellol & 1198 & 2.11 & 2.63 & 1.74 & 1.42 & 2.43 & $\mathrm{a}, \mathrm{b}, \mathrm{c}$ & & & & - & - & $\mathrm{t}$ & - & - & \\
\hline 25 & Nerol & 1198 & $\mathrm{~T}$ & - & 0.62 & 0.60 & - & $a, b, c$ & & & & $\begin{array}{l}0.091 \pm \\
0.034\end{array}$ & $\begin{array}{l}0.069 \pm \\
0.011\end{array}$ & $\begin{array}{l}0.065 \pm \\
0.016\end{array}$ & $\begin{array}{l}0.079 \pm \\
0.004\end{array}$ & $\begin{array}{l}0.076 \pm \\
0.028\end{array}$ & \\
\hline 26 & Pulegone & 1198 & 1.40 & 1.76 & 1.70 & 1.57 & 1.58 & $\mathrm{a}, \mathrm{b}, \mathrm{c}$ & & & & & & & & & \\
\hline 27 & Neral & 1230 & 28.25 & 24.45 & 22.67 & 27.90 & 22.72 & $\mathrm{a}, \mathrm{b}, \mathrm{c}$ & & & & & & & & & \\
\hline 28 & Chavicol & 1243 & 1.42 & - & - & 1.04 & - & $\mathrm{a}, \mathrm{b}, \mathrm{c}$ & & & & & & & & & \\
\hline
\end{tabular}
traces $n \mathbf{i}=$ not identified. 

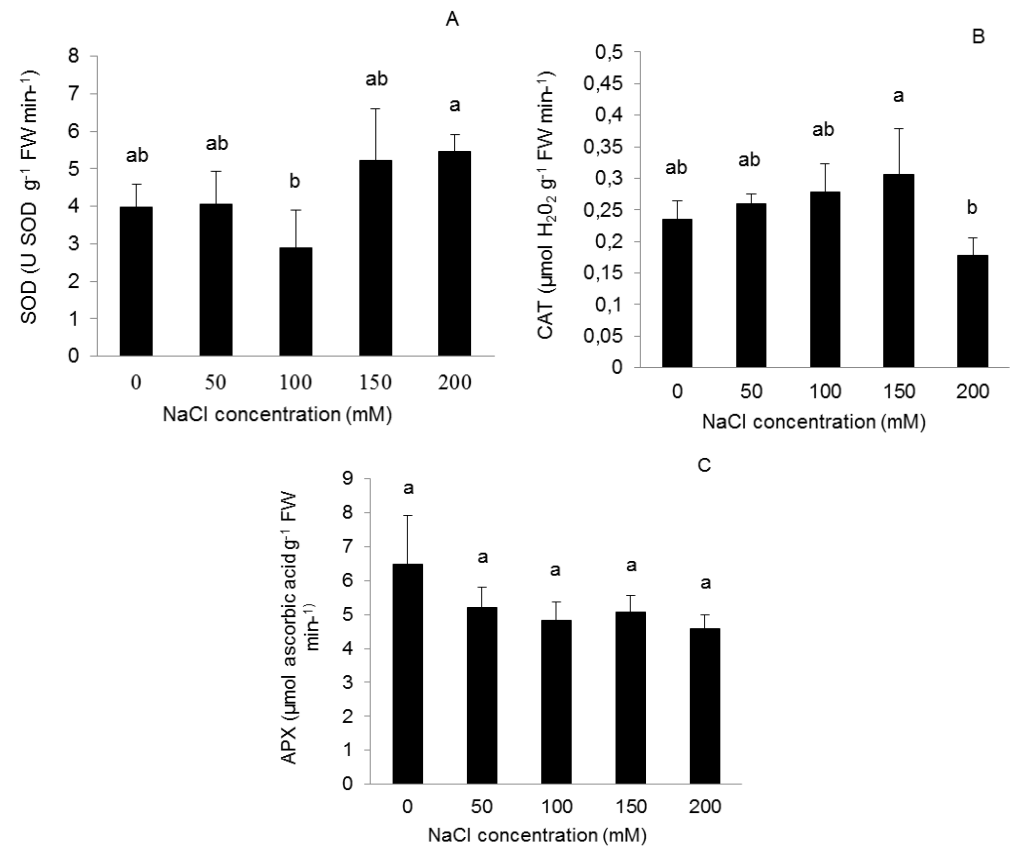

Fig 4. Antioxidant responses of the enzymes SOD (A), CAT (B), and APX (C) due to the effects of salinity stress. Means followed by the same letter did not differ significantly at $\mathrm{p}<0.05$, according to Tukey's test.

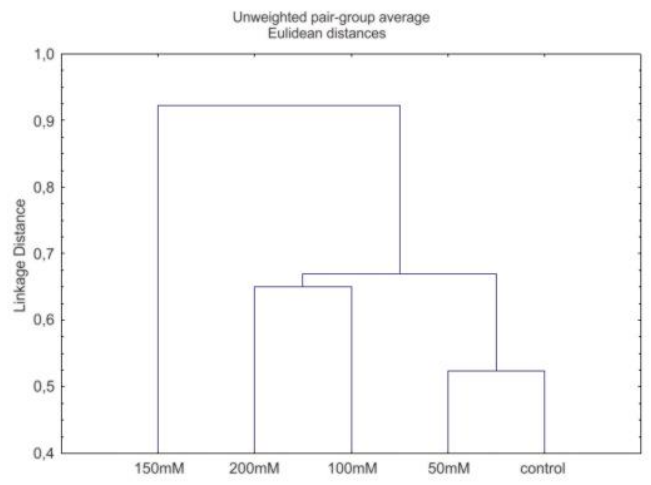

Fig 5. Hierarchical clustering dendrogram obtained in the cluster analysis of the essential oils of Melissa officinalis L. leaves treated with different $\mathrm{NaCl}$ concentrations. Data extracted from Table 2.

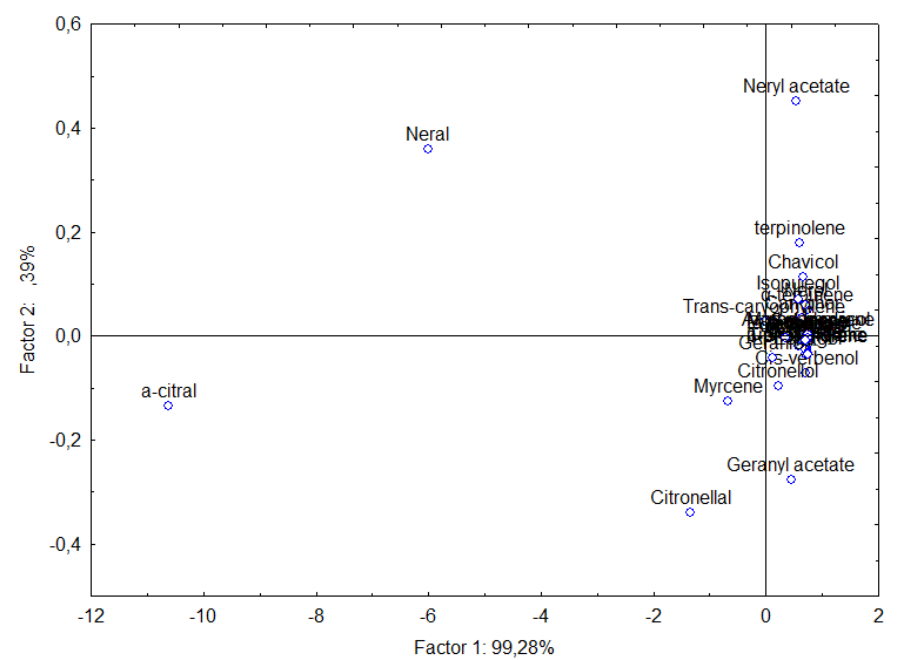

Fig 6. A biplot representation of the essential oil (OE) of Melissa officinalis L. plants subject to $\mathrm{NaCl}$ stress according to the principal component analysis (PCA). 
The APX is located mainly in chloroplasts and partially in cytosols. This is another enzyme of defense that uses $\mathrm{H}_{2} \mathrm{O}_{2}$ as substrate (Çoban et al., 2016). The results observed in the current study suggest that the CAT and SOD differed significantly, the APX activity did not present significant differences among treatments; however, decreased activity was observed in lemon balm plants subjected to salt stresses (Fig. 4C.). Sabra et al. (2012) compared some enzymatic activities at three $\mathrm{NaCl}$ concentrations $(50,75$ and $100 \mathrm{mM})$ in three Echinacea species (E. purpurea, E. pallida, and E. angustifolia) and observed that SOD and APX were effective only in E. purpurea. Reduction of the CAT activity was observed at the concentrations of $75 \mathrm{mM}$ and $100 \mathrm{mM} \mathrm{NaCl}$ in the three Echinacea species evaluated (Sabra et al. 2012). According to these authors, it probably occurred due to the enzymatic interactions that eliminated superoxide radicals $\left(\mathrm{O}_{2}{ }^{\circ}\right)$ and $\mathrm{H}_{2} \mathrm{O}_{2}$ molecules present in cell metabolisms of plants submitted to $\mathrm{NaCl}$ stress. With respect to the enzymatic antioxidant mechanisms, our results indicate that the evaluation of resistance to salt stress should be conducted with moderation, taking into account the plant growth stages.

\section{Effects of salt stress on yield and chemical composition of lemon balm's essential oil}

Essential oils are secondary metabolites that contain various compounds. Lemon balm plants are rich in essential oils that are widely used in food and healthcare products, medicines, and cosmetics (Mokhtarzadeh et al., 2016). The commercial value of lemon balm plants depends on the yield and chemical composition of their essential oils. In this study, the salt stress reduced the content of essential oils in lemon balm plants. In control plants, the EO yield was $0.091 \%$ and the plants subjected to salt stress showed reduced levels of essential oils for the different $\mathrm{NaCl}$ concentrations (Table 2). Moderate and high levels of salinity (150 and $200 \mathrm{mM}$ ) resulted in EO yields of 0.079 and $0.076 \%$, respectively. Low levels of $\mathrm{NaCl}(50$ and $100 \mathrm{mM})$ resulted in a decreased $\mathrm{EO}$ production of $M$. officinalis. These results suggest that lemon balm plants are sensitive to salinity and high concentrations of $\mathrm{NaCl}$ in soil would decrease the $\mathrm{EO}$ biosynthesis in these plants. Aziz et al. (2008), suggested that the reduced levels of EO production could be due tothe decreased photosynthesis and/or further alterations in metabolism. Any alteration in the normal plant metabolism can affect the EO biosynthesis and therefore decreasethe EO yield (Srivastava et al., 1998; Çoban et al., 2016). Some authors reported significant reductions in the total EO content in different medicinal species subjected to salt stress (Aziz et al., 2008; Khorasaninejad et al., 2010; Çoban et al., 2016).

Forty-five compounds were identified in the EO of $M$. officinalis leaves, $97.66 \%$ of them belonged to four chemical classes: monoterpene hydrocarbons, oxygenated monoterpenes, sesquiterpene hydrocarbons, and oxygenated sesquiterpenes. The predominant class was oxygenated monoterpenes and the major compounds identified in all $\mathrm{NaCl}$ treatments were $\alpha$-citral $(\mathrm{TC}=45.05 \%$; $\mathrm{T} 50=42.22 \%$; $\mathrm{T} 100=41.38 \% ; \mathrm{T} 150=41.78 \%$ and $\mathrm{T} 200=40.45 \%$ ); neral $(\mathrm{TC}=28.25 \% ; \mathrm{T} 50=24.45 \% ; \mathrm{T} 100=22.67 \% ; \mathrm{T} 150=27.90 \%$ and $\mathrm{T} 200=22.72 \%)$; citronellal $\quad(\mathrm{TC}=9.89 \%$; $\mathrm{T} 50=8.93 \%$; $\mathrm{T} 100=5.87 \% ; \mathrm{T} 150=5.51 \%$ and $\mathrm{T} 200=9.13 \%)$. In addition to these compounds, myrcene, trans-caryophyllene, citronellol, pulegone, and linalool were also identified in all the treatments, but in lower concentration (Table 2). These compounds are commonly found in the EO of M. officinalis leaves; however, their occurrence may vary with local cultivation method, environment conditions and EO extraction method (Tagashira and Ohtake, 1998; Silva et al., 2005; Khalid and Cail, 2011; Szabó et al., 2016). In addition to alterations in the percentage of major compounds, the different $\mathrm{NaCl}$ concentrations induced an increased number of compounds as identified in the $\mathrm{EO}$ of all the $\mathrm{NaCl}$ treatments (Table 2). The same was observed by Taarit et al. (2011), who reported an increased amount of compounds in Salvia esclarea L. Some compounds such as cis-verbenol $(1.18 \%)$, estragole $(0.62 \%)$ and $p$-cymene $(0.19 \%)$ were exclusively found at $200 \mathrm{mM} \mathrm{NaCl}$, the highest salt concentration. High production of compounds at high salinity concentrations probably occurred due to the increased enzymatic activity for the EO biosynthesis (Taarit et al., 2010; Khalid and Cail, 2011).

The hierarchical analysis was applied to understand the chemical variability of the EO of $M$. officinalis plants subjected to salt stress. A dendrogram was obtained based on the Unweighted Pair Group Method with Arithmetic Mean (UPGMA), which grouped data into three main clusters classified by salinity levels. The first cluster included the control and the low salinity level represented by $50 \mathrm{mM} \mathrm{NaCl}$ treatment. The second cluster was formed by the higher levels of salinity, represented by 100 and $200 \mathrm{mM} \mathrm{NaCl}$ treatments. The third cluster included only the $150 \mathrm{mM} \mathrm{NaCl}$ treatment (Fig. 6.). The clustering showed three groups distinguishing by salinity level, in which above $100 \mathrm{mM}$ $\mathrm{NaCl}$, the EO biosynthesis was modified to alter the quantity and quality of compounds of the lemon balm's EO (Table 2, Fig. 5.)

Principal Component Analysis (PCA) allows conjointly evaluating all variables in the analysis. In the present study, a PCA was performed in order to investigate the behavior of the chemical components of the EO of M. officinalis plants subjected to different $\mathrm{NaCl}$ concentrations. The PCA analysis showed a total variance of $99.67 \%$, in which the principal components PC1 and PC2 explained $99.28 \%$ and $0.39 \%$ of the total variance, respectively (Fig. 6.). It was observed that some EO compounds moved away from each other (Fig. 5.). The results of the PCA corresponded to those obtained in the cluster analysis (Figs. 5 and 6). Citronellal, $\alpha$-citral, and neral were positioned far from the others, forming three distinct groups. Although predominant and present in all treatments, $\alpha$-citral and neral decreased to $10.21 \%$ and $19.58 \%$ respectively, at $200 \mathrm{mM} \mathrm{NaCl}$, in comparison with control. The same was observed for citronellal, which shows decline by $40.64 \%$ and $44.28 \%$ in the concentrations of 100 and $150 \mathrm{mM} \mathrm{NaCl}$, respectively. Neryl-acetate and geranyl-acetate were exclusively found in plants subjected to salt stress, neryl-acetate was detected at $150 \mathrm{mM} \mathrm{NaCl}$ and geranylacetate at 100 and $200 \mathrm{mM} \mathrm{NaCl}$. These two compounds were split into two different clusters by the PCA analysis. Probably this monoterpene production occurred due to the activation of a metabolic pathway that produces terpenoids and consequently monoterpenes, which have an important role in protecting plants against abiotic stresses (Loreto and Velikova, 2001; Loreto et al., 2004; Holopainen and Gershenzon, 2010; Savoi et al., 2016).

The highest EO production was observed in lemon balm plants treated with $\mathrm{NaCl}$, in which different classes of compounds were detected. It suggests that the production of isoprenoids (monoterpenes and sesquiterpenes) occurs even under stress conditions, when photosynthesis is almost or completely inhibited or when carbon is unavailable (Monson and Fall, 1989; Brili et al., 2007). This suggests that under stress conditions isoprenoids have benefited plants in adverse environments (Siemens et al., 2002). These compounds can activate responses to oxidative stress since they are lipophilic 
and can physically stabilize hydrophobic interactions in cell membranes, minimizing lipid peroxidation, reducing oxidative stress and ROS accumulation (Vickers et al., 2009).

\section{Materials and methods}

\section{Plant materials}

The lemon balm seeds $\left(\right.$ TOPSEED $^{\circledR}$ ) were immersed in distilled water for $48 \mathrm{~h}$ at $6^{\circ} \mathrm{C}$ to break seed dormancy. Then, the seeds were sown in polystyrene tray containing commercial substrate $\left(\right.$ Carolina Padrão ${ }^{\circledR}$ ). Five seeds were distributed on each tray cell and subjected to daily irrigation. The experiment was conducted in a greenhouse conditions with an average a $16 \mathrm{~h}$ light $/ 8 \mathrm{~h}$ dark regimen at $24^{\circ} \mathrm{C}$ day $/ 14^{\circ} \mathrm{C}$ night temperature in a random block design. The 30 -day-old seedlings were transplanted to $3 \mathrm{~L}$ plastic pots containing soil, sand, and organic compost in $2: 1: 1$. One seedling per pot and nine pots per treatment were tested for four concentrations of sodium chloride (50, 100, 150 and 200 $\mathrm{mM} \mathrm{NaCl}$ ) (Khorasaninejad et al., 2010; Roodbari et al., 2013). The seedlings treated with water were maintained as control. The concentrations of salt solutions were gradually increased to $50 \mathrm{mM} \mathrm{NaCl}$ every week, in order to avoid osmotic shock, until the completion of each treatment. Plants were irrigated with Hoagland solution (Hoagland and Arnon, 1950) weekly, until the end of the experiment. The plant material was collected after 60 days of stress and stored at $80^{\circ} \mathrm{C}$ in ultra-freezer, in a hermetically sealed container, until analysis.

\section{Morphological evaluation}

\section{Shoot height and shoot fresh mass}

Plant shoot heights $(\mathrm{SH})(\mathrm{cm})$ were obtained by tape measure, from the lap of the plant to the apex. The shoot fresh masses (SFM) (g) were weighed by an analytical balance.

\section{Biochemical analysis}

\section{Chlorophyll content measurement}

Total chlorophyll content was measured in five leaves of the middle third with three biological replications of each treatment, using the ClorofiLOG ${ }^{\circledR}$ chlorophyll meter model CFL 1030, according to the manufacturer's instructions (Falker®).

\section{Relative water content}

Parameters for relative water content (RWC \%) were recorded in five leaves of the middle third with three biological replications of each treatment, according to Rouached et al. (2013). Then, the RWC calculation was performed using the following equation (Schonfeld et al., 1988):

$R W C=\frac{F M-D M}{T M-D M} \times 100$

Where:

RWC\% = relative water content in plants;

$\mathrm{FM}=$ fresh mass weight;

$\mathrm{DM}=$ dry mass weight;

$\mathrm{TM}=$ turgid mass weight.

\section{Water activity}

The water activity (aw) was determined in leaves using the Lab Master-aw apparatus, Novasina-Tecnal®. Ten $1 \mathrm{~cm}-$ diameter discs were collected in the middle third with three biological replications of each treatment and placed into the apparatus for analysis.

\section{Plasma membrane integrity}

Membrane permeability was measured through relative electrolyte leakage (REL) with an ITMCA $150 \mathrm{P} \AA$ microprocessed portable electric conductivity meter, according to the method described by Wang et al. (2005). Ten $1 \mathrm{~cm}$ diameter discs were collected in the middle third with three biological replications for each treatment. The damage in the membrane (DM\%) was obtained by the following equation:

$$
R E L=\left(\frac{L 1}{L 2}\right) \times 100
$$

Where:

REL\% = relative electrolyte leakage;

L1 = initial electric conductivity of the extract;

L2 = final electric conductivity of the extract.

\section{Antioxidant enzymes}

Plant tissues were collected in liquid nitrogen and transferred to the experimental laboratory. Samples of approximately 0.3 $\mathrm{g}$ were homogenized in $1.5 \mathrm{~mL}$ of $200 \mathrm{mM}$ potassium phosphate buffer ( $\mathrm{pH} 7.8$ ) containing $10 \mathrm{mM}$ EDTA, 200 $\mathrm{mM}$ ascorbic acid and $10 \%$ of polyvinylpolypyrrolidone (PVPP) using pestle and mortar. The homogenate was centrifuged at $12,000 \mathrm{~g}$ for $20 \mathrm{~min}$ at $4^{\circ} \mathrm{C}$ and the supernatant was collected and stored in ultra-freezer $\left(-80^{\circ} \mathrm{C}\right)$ until analysis. The extracts were used for testing the antioxidant enzymes superoxide dismutase (SOD), catalase (CAT) and ascorbate peroxidase (APX). All assays were performed with three biological replications in triplicate.

\section{SOD enzyme (EC 1.15.1.1)}

The SOD activity is based on its ability to inhibit the reduction of nitrobluetetrazolium (NBT) by superoxide, forming blue formazan, as described by Giannopolitis and Ries (1977). The reaction medium (1mL) consisted of $50 \mathrm{mM}$ $\mathrm{KPO}_{4}$ buffer (pH 7.8), $13 \mathrm{mM}$ methionine, $0.1 \mu \mathrm{M}$ EDTA, 75 $\mu \mathrm{M}$ NBT, $2 \mu \mathrm{M}$ riboflavin and $50 \mu \mathrm{L}$ of the crude sample extract. Absorbance was read at $560 \mathrm{~nm}$ and the SOD activity was expressed as $\mathrm{U} \mathrm{SOD} \mathrm{g}^{-1} \mathrm{FW} \mathrm{min}^{-1}$, where a unit of (U) SOD activity was defined as the amount of enzyme required to inhibit $50 \%$ of the NBT reduction. Analyses were performed in triplicate.

\section{CAT enzyme (EC 1.11.1.6)}

The CAT activity was determined according to methodology described by Havir and McHale (1987). The reaction medium $(1 \mathrm{~mL})$ consisted of $200 \mathrm{mM} \mathrm{KPO}$ buffer (pH 7.0), $20 \mathrm{mM}$ $\mathrm{H}_{2} \mathrm{O}_{2}$ and $50 \mu \mathrm{L}$ of the crude sample extract. Catalase activity was determined by the $\mathrm{H}_{2} \mathrm{O}_{2}$ consumption monitored by spectrophotometry at $240 \mathrm{~nm}$ for 1 minute and quantified using the $36 \mathrm{M}^{-1} \mathrm{~cm}^{-1}$ molar extinction coefficient (Anderson et al., 1995). The CAT activity was expressed in $\mu_{\text {molH }} \mathrm{O}_{2} \mathrm{~g}$ ${ }^{1} \mathrm{FW} \mathrm{min}^{-1}$. Analyses were performed in triplicate. 


\section{APX enzyme (EC 1.11.1.11)}

Ascorbate peroxidase catalyzes the reduction of $\mathrm{H}_{2} \mathrm{O}_{2}$ to $\mathrm{H}_{2} \mathrm{O}$ by oxidizing ascorbate. The APX activity was determined according to methodology described by de Nakano and Asada (1981). The reaction medium $(1 \mathrm{~mL})$ consisted of 50 $\mathrm{mM} \mathrm{KPO}_{4}$ buffer (pH 7.0), $10 \mathrm{mM}$ ascorbic acid, $1 \mathrm{mMH}_{2} \mathrm{O}_{2}$ and $50 \mu \mathrm{L}$ of the crude sample extract. APX activity was determined by the $\mathrm{H}_{2} \mathrm{O}_{2}$ degradation monitored by spectrophotometry at $290 \mathrm{~nm}$ for 1 minute and quantified using the $2.8 \mathrm{mM}^{-1} \mathrm{~cm}^{-1}$ molar extinction coefficient (Nakano and Asada, 1981). The APX activity was expressed as $\mu$ mol ascorbic acid $\mathrm{g}^{-1} \mathrm{FW} \mathrm{min}^{-1}$. Analyses were performed in triplicate.

\section{Lemon balm EO extraction}

The EO extraction of $100 \mathrm{~g} / \mathrm{L}$ lemon balm fresh leaves was made by hydrodistillation for $3 \mathrm{~h}$ (Verma et al., 2015). The lemon balm's EO was extracted with n-Hexane, filtered with anhydrous sodium sulfate $\left(\mathrm{Na}_{2} \mathrm{SO}_{4}\right)$ and kept under refrigeration $\left(4^{\circ} \mathrm{C}\right)$ until total solvent evaporation (Brasil, 2010).

\section{Chemical analysis of EO by GC/MS}

The essential oil was subjected to GC/MS analysis using Agilent $^{\circledR}$ (7890B) gas chromatograph coupled to Agilent ${ }^{\circledR}$ (5977A) mass spectrometer. The fused silicacapillary column was HP-5MS $(30 \mathrm{~m} \times 0.25 \mathrm{~mm} \times 0.25 \mu \mathrm{m})$. The conditions of the equipment were the same as those used by Verma et al. (2015). Helium was used as carrier gas at a flow rate of $1 \mathrm{~mL}$ $\mathrm{min}^{-1}$. The temperature of the injector was maintained at 220 ${ }^{\circ} \mathrm{C}$. The essential oil samples were diluted with dichloromethane (1:10), the injection volume was $2.0 \mu \mathrm{L}$ and split mode (1:30). The temperatures of the transfer line, ions source, and quadrupole were 285,230 and $150{ }^{\circ} \mathrm{C}$, respectively. The column temperature was initially programmed at $60{ }^{\circ} \mathrm{C}$, heated at $2{ }^{\circ} \mathrm{C} \min ^{-1}$ to reach the temperature of $180^{\circ} \mathrm{C}$ for 4 minutes, and then heated at $10^{\circ} \mathrm{C}$ $\mathrm{min}^{-1}$ to reach $260^{\circ} \mathrm{C}$ and lastly heated at $40^{\circ} \mathrm{C} \mathrm{min}^{-1}$ to reach the final temperature of $300^{\circ} \mathrm{C}$. The detection system was MS with scan mode in the mass/charge range of $40-550 \mathrm{~m} / \mathrm{z}$ with "Solvent Delay" of $3 \mathrm{~min}$. The retention indices (RI) of compounds of the essential oils were determined based on the alkane series C7-C26. EO chemical compounds were identified by comparison of their mass spectra with the mass spectra in the NIST 11.0 library and by means of their retention indices, compared with those in the literature (Adams, 2007).

\section{Statistical analysis}

The completely randomized statistical design was applied for the four concentrations of $\mathrm{NaCl}(50,100,150$ and $200 \mathrm{mM})$ and the control (without $\mathrm{NaCl}$ ), with nine replications per treatment. Data were submitted to analysis of variance (ANOVA) and the means compared by the Tukey mean test $(\mathrm{p}<0.05)$ using the software Sisvar v. 5.6 (Ferreira, 2011). Cluster analysis (CA) and principal component analysis (PCA) were performed in order to discriminate the essential oil composition based on different $\mathrm{NaCl}$ levels. Variables were analyzed by the software Statistica v 13.3 (STATSOFT., 2017).

\section{Conclusion}

Conclusively, the development of $M$. officinalis was negatively affected by salt stress. Decreases in growth, biomass accumulation and water potential of shoots were some of the apparent responses to salinity. In addition, salinity also caused physiological disturbances such as chlorosis. Necrosis was also observed in plants subjected to high concentrations of $\mathrm{NaCl}(100,150$ and $200 \mathrm{mM})$, as a consequence of decreased chlorophyll content and increased membrane damage. Our results demonstrated that lemon balm plants are tolerant to low salinity concentrations (up to $50 \mathrm{mM}$ ). Different metabolic responses were identified in this species. Plants subjected to higher $\mathrm{NaCl}$ concentrations presented an increased activity of the antioxidant enzymes including SOD and CAT, in addition to a secondary metabolism, maintained by the production of essential oil. The monoterpene synthesis was influenced by salinity, mainly the compounds neryl-acetate and geranyl-acetate, which are responsible for protecting plants against different environmental stresses.

\section{Acknowledgments}

To the Coordenação de Aperfeiçoamento de Pessoal de Nível Superior (CAPES) for the grants to CB and CBT; and to the Universidade Paranaense (UNIPAR) for the research's financial support.

\section{References}

Abbaszadeh B, Farahani HA, Valadabadi SA, Darvishi HH (2009) Nitrogenous fertilizer influence on quantity and quality values of balm (Melissa officinalis L.). J Agric Ext Rural Dev. 1(1):31-33.

Adams RP (2017) Identification of Essential oil Components by Gas Chromatography/Mass Spectrometry. 4 ed. Carol Stream, Illinois: Allured Publishing Corporation, 804p.

AlscherRG, Erturk N, Heath LS (2002) Role of superoxide dismutates (SODs) in controlling oxidative stress in plants. J Exp Bot. 53(372):1331-1341.

Alvarenga ICA, Valadares RV, Martins ER, Oliveira FG, Figueiredo LS, Kobayashi MK (2011) Water stress before harvest of pepper-rosmarin. Pesqui Agropecu Bras. 46(7):706-711.

Anderson MD, Prasad TK, Stewart CR (1995) Changes in isozyme profiles of catalase, peroxidase, and glutathione reductase during acclimation to chilling in mesocotyls of maize seedlings. Plant Physiol. 109(4):1247-1257.

Argyropoulos D, Müller J (2014) Changes of essential oil content and composition during convective drying of lemon balm (Melissa officinalisL.). Ind Crops Prod. 52:118-124.

Aziz EE, Al-Amier H, Craker LE (2008) Influence of salt stress on growth and essential oil production in peppermint, pennyroyal, and apple mint. J Herbs Spices Med Plants 14:3-9.

Bagdat RB, Cosge B (2006) The essential oil of lemon balm (Melissa officinalis L.), its components and using fields. J Fac Agric. 21(1):116-121.

Baghalian SH, Abdoshah F, Khalighi-Sigaroodi F, Paknejad F (2011) Physiological and phytochemical response to drought stress of German chamomile (Matricaria recutita L.). Plant Physiol Biochem. 49(2):201-207.

Brasil (2010) Agência Nacional de Vigilância Sanitária (ANVISA).5rd edn. Anvisa, Brasília. 
Bray EA, Bailey-Serres J, Weretilinik E (2000) Responses to abiotic stresses. In: Buchanan BB, Gruissem W, Jones RL (ed) Biochemistry and molecular biology of plants. Rockville: American Society of Plant Physiologists, 11581249p.

Brilli F, Barta C, Fortunati A, Lerdau M, Loreto F, Centritto M (2007) Responses of isoprene emission and carbon metabolism to drought in White poplar (Populus alba) saplings. New Phytol. 175(2):244-254.

Chen C, Letnik I, HachamY, Dobrev P, Ben-Daniel BH, Vankova R, Amir R, Miller G (2014) Ascorbate peroxidase protects Arabidopsis desiccating and germinating seeds from stress and mediates cross talk between reactive oxygen species, abcisic acid, and auxin. Plant Physiol. 166(1):370-383.

ChoudhuryFK, Rivero RM, Blumwald E, Mittler R (2016) Reactive oxygen species, abiotic stress and stress combination. Plant J. 90(5):856-867.

ÇobanO, Baydar NG (2016) Brassinosteroid effects on some physical and biochemical properties and secondary metabolite accumulation in peppermint (Mentha piperita L.) under salt stress. Ind Crops Prod. 86:251-258.

Farooq M, Wahid A, Kobayashi N, Fujita D, Basra SMA (2009) Plant drought stress: effects, mechanisms and management. Agron Sustain Dev. 29(1):185-212.

Ferreira DF (2011)Sisvar: a computer statistical analysis system. Ciênc Agrotec. 35 (6):1039-1042.

Giannopolitis I, Ries SK (1977) Superoxide dismutases: I. Occurrence in higher plants. Plant Physiol. 59(2):309-314.

Gill SS, Tuteja N (2010) Reactive oxygen species and antioxidant machinery in abiotic stress tolerance in crop plants. Plant Physiol Biochem. 48(12):909-930.

Havir EA, McHale NA (1987) Biochemical and developmental characterization of multiple forms of catalase in tobacco leaves. Plant Physiol. 84(2):450-455.

Hoagland DR, Arnon DI (1950) The water culture method for growing plants without soils. Calif Agric Exp Stn Circ. 347:1-32.

Holopainen JK, Gershenzon J (2010) Multiple stress factors and the emission of plant VOCs. Trends Plant Sci. 15(3):176-184.

Hu Z, Shen Y, Shen F, Su X (2009) Effects of feeding Clostera anachoreta on hydrogen peroxide accumulation and activities of peroxidase, catalase, and ascorbate peroxidase in Populussimonii x $P$. pyramidalis 'Opera 8277' leaves. Acta Physiol Plant. 31:995-1002.

Hussain A, Anwar F, Iqbal T, Bhatti I (2011) Antioxidant attributes of four Lamiaceae essential oils. Pak J Bot. 43(2):1315-1321.

Jaspers P, Kangasjarvi J (2010) Reactive oxygen species in abiotic stress signaling. Physiol Plant. 138(4):405-413.

Kasrati A, Jamali CA, Bekkouche K, Wohlmuth H, Leach D, Abbad A (2014) Plant growth, mineral nutrition and volatile oil composition of Mentha suaveolens subsp. timija (Briq.) Harlby cultivated under salt stress conditions. Ind Crops Prod. 59:80-84.

Kere GM, Guo Q, Chen J (2016) Growth and physiological responses of cucumber (Cucumis sativus L.) to sodium chloride stress under solid hydroponics. J Environ Agric Sci. 6:47-57.

Khalid AK, CailW (2011) The effects of manitol and salinity stresses on growth and biochemical accumulations in lemon balm. Act Ecol Sin. 31:112-120.
Khorasaninejad S, Mousavi A, Soltanloo H, Hemmati K, Khalighi A (2010) The Effect of Salinity Stress on Growth Parameters, Essential oil Yield and Constituent of Peppermint (Mentha piperita L.). World Appl Sci J. 11(11):1403-1407.

Kim S, Yun EJ, BakJS, Lee H, Lee SJ, Kim CT, Lee JH, Kim KH (2010) Response surface optimised extraction and chromatographic purification of rosmarinic acid from Melissa officinalis leaves. Food Chem. 121:521-526.

Kumar T, Khan MR, Abbas Z, Ali GM (2014) Genetic improvement of sugarcane for drought and salinity stress tolerance using Arabidopsis vacuolar pyrophosphatase (AVP1) gene. Mol Biotechnol. 56(3):199-209.

Lledias F, Rangel P, Hansberg W (1998) Oxidation of catalase by singlet oxygen. J Biol Chem. 273(17):1063010637.

Lopes NP, Gobbo-Neto L (2007) Plantas medicinais: fatores de influência no conteúdo de metabólitos secundários. Quim Nova 30(2):374-381.

Loreto F, Velikova V (2001) Isoprene produced by leaves protects the photosynthetic apparatus against ozone damage, quenches ozone products, and reduces lipid peroxidation of cellular membranes. Plant Physiol. 127(4):1781-1787.

Loreto F, Pinelli P, Manes F, Kollist H (2004) Impact of ozone on monoterpene emissions and evidence for an isoprene-like antioxidant action of monoterpenes emitted by Quercus ilex leaves. Tree Physiol. 24(4):361-367.

Meira MR, Martins ER, Manganotti AS (2012) Crescimento, produção de fitomassa e teor de óleo essencial de melissa (Melissa officinalis L.) sob diferentes níveis de sombreamento. Rev Bras Pl Med. 14(2):352-357.

Monson RK, Fall R (1989) Isoprene emission from aspen leaves: influence of environment and relation to photosynthesis and photorespiration. Plant Physiol. 90(1):267-274.

Moradkhani H, Sargsyan E, Bibak H, Naseri B, SadatHosseini M, Fayazi-Barjin A, Meftahizade H (2010) Melissa officinalis $\mathrm{L}$., a valuable medicine plant: a review. J Med Plant Res. 4(25):2753-2759.

Mokhtarzadeh S, Demirci B, Goger G, Khawar KM, Kirimer $N$ (2016) Characterization of volatile components in Melissa officinalis L. under in vitro conditions. J Essent Oil Res. 29(4):299-303.

Morgan R (1994) Enciclopédia das ervas e plantas medicinais. Hemus, São Paulo.

Munns R (2002) Comparative physiology of salt and water stress. Plant Cell Environ. 25(2):239-250.

Munns R, Tester M (2008) Mechanisms of salinity tolerance. Annu Rev Plant Biol. 59:651-681.

Nakano Y, Asada K (1981) Hydrogen peroxide is scavenged by ascorbate specific peroxidase in spinach chloroplasts. Plant Cell Physiol. 22(5):867-880.

Negrão S, Schmöckel SM, Tester M (2017) Evaluating physiological responses of plants to salinity stress. Ann Bot. 119(1):1-11.

Ozturk A, Unlukara A, Ipek A, Gurbuz B (2004) Effects of salt stress and water deficit on plant growth and essential oil content of lemon balm (Melissa officinalis L.). Pak J Bot. 36(4):787-792.

Reddy VS, Day IS, Thomas T, Reddy AS (2004) KIC, a novel $\mathrm{Ca}^{2+}$ binding protein with one EF-hand motif, interacts with a microtubule motor protein and regulates trichome morphogenesis. Plant Cell. 16(1):185-200. 
Roodbari N, Roodbari S, GanjaliA, Nejad FS, Ansarifar M (2013) The effects of salinity stress on growth parameters and essential oil percentage of peppermint (Mentha piperita L.). Int JAdv Biol Biom Res. 1(9):1009-1015.

Rouached A, Slama I, Zorrig W, Jdey A, Cukier C, Rabhi M, Talbi O, Limami AM, Abdelly C (2013) Differential performance of two forage species: Medicago truncatula and Sulla carnosa under water deficit stress and recovery. Crop Pasture Sci. 64(3):254-264.

Sabra A, Daayf F, Renault S (2012) Differential physiological and biochemical responses of three Echinacea species to salinity stress. Sci Hort. 135:2331.

Savoi S, Wong DCJ, Arapitsas P, Miculan M, Bucchetti B, Peterlunger E, Fait A, Mattivi F, Castellarin SD (2016) Transcriptome and metabolite profiling reveals that prolonged drought modulates the phenylpropanoid and terpenoid pathway in white grapes (Vitis vinifera L.). BMC Plant Biol. 16:2-17.

Scandalios JG (2005) Oxidative stress: molecular perception and transduction of signals triggering antioxidant gene defenses. Braz J Med Biol Res. 38(7):995-1014.

Schonfeld MA, Johnson RC, Carwer BF, Mornhinweg DW (1988) Water relations in winter wheat as drought resistance indicators. Crop Sci. 28:526-531.

Siemens DH, Garner SH, Mitchell-Olds T, Callaway RM (2002) Cost of defense in the context of plant competition: Brassica rapa may grow and defend. Ecology 83(2):505517.

Silva AS (2002) Análise técnica econômica e de tendências da indústria brasileira de óleos essenciais. Papel Virtual, Rio de Janeiro. 202 p

Silva S, Sato A, Lage CLS, Gil RASS, Azevedo DA, Esquibel MA (2005) Essential Oil Composition of Melissa officinalis L. in vitro Produced under the Influence of Growth Regulators. J Braz Chem Soc. 16(6):1387-1390.

Srivastava NK, Misra A, Sharma S (1998) The substrate utilization and concentration of C-14 photosynthases in citronela under $\mathrm{Fe}$ deficiency. Photoshynthetica 35:391398.

STATSOFT (2017) Statistica for Windows [Computer program manual]. v. 13.3. Tulsa: StatSoft. Available at: <http://www.statsoft.com>. Acessed 15 Aug 17.

Suzuki N, Koussevitzky S, Mittler R, Miller G (2012) ROS and redox signalling in the response of plants to abiotic stress. Plant Cell Environ. 35:259- 270.
Szabó K, Malekzadeh M, Radácsi P, Ladányi M, Rajhárt P, Inotai K, Tavaszi-Sárosi S, Németh É (2016) Could the variety influence the quantitative and qualitative outcome of lemon balm production? Ind Crops Prod. 83:710-716.

Taarit MB, Msaada K, Hosni K, Marzouk B (2010) Changes in fatty acid and essential oil composition of sage (Salvia officinalis L.) leaves under $\mathrm{NaCl}$ stress. Food Chem. 119:951-956.

Taarit MB, Msaada K, Hosni K, Marzouk B (2011) Physiological changes and essential oil composition of clary sage (Salvia sclarea L.) rosette leaves as affected by salinity. Acta Physiol Plant. 33:153-162.

Tagashira M, Ohtake Y (1998) A new antioxidative 1,3benzodioxole from Melissa officinalis. Planta Med. 64:555558.

Tonelli M, Pellegrini E, D’Angiolillo F, Petersen M, Nali C, Pistelli L, Lorenzini G (2014) Ozone-elicited secondary metabolites in shoot cultures of Melissa officinalis L. Plant Cell Tissue Organ Cult. 120 (2):617-629.

Tounekti T, Abreu ME, Khemira H, Munné-Bosch S (2012) Canopy position determines the photoprotective demand and antioxidante protection of leaves in salt-stressed Salvia officinalis L. plants. Environ Exp Bot. 78:146-156.

Tripathy BC, Oelmüller R (2012) Reactive oxygen species generation and signaling in plants. Plant Signal Behav. 7(12):1621-1633.

Verma RS, Rajendra CP, Chauhan A (2015) Evaluation of essential oil quality of lemon balm (Melissa officinalis L.) grown in two locations of northern India. J Essent Oil Res.1-6.

Vickers CE, Gershenzon J, Lerdau MT, Loreto F (2009) A unified mechanism of action for volatile isoprenoids in plant abiotic stress. Nat Chem Biol. 5(5):283-291.

Wang YS, Tian SP, Xu Y (2005) Effects of high oxygen concentration on pro- and anti-oxidant enzymes in peach fruits during postharvest periods. Food Chem. 91:99-104.

Yasar F, Kusvuran S, Ellialtioglu S (2006) Determination of anti-oxidant activities in some melon (Cucumis melo $\mathrm{L}$.) varieties and cultivars under salt stress. J Hortic Sci Biotechnol. 81(4):627-630.

Younesi O, Moradi A (2015) Effect on different priming methods on germination and seedling establishment of two medicinal plants under salt stress conditions. Cercet Agro Moldova 48(3):43-51. 